\section{Access to medicines among internally displaced and non-displaced people in urban areas in Colombia}

\author{
Acceso a medicamentos por población desplazada \\ y no desplazada en zonas urbanas en Colombia
}

\author{
1 Escuela de Medicina, \\ Universidad Industrial de \\ Santander, Bucaramanga, \\ Colombia. \\ 2 Centro de Investigación en \\ Sistemas de Salud, Instituto \\ Nacional de Salud Pública, \\ Cuernavaca, México. \\ 3 Cardiovascular Foundation \\ of Colombia, Floridabalanca, \\ Colombia. \\ Correspondence \\ V. J. Wirtz \\ Centro de Investigación en \\ Sistemas de Salud, Instituto \\ Nacional de Salud Pública. \\ Avenida Universidad 655 . \\ Cuernavaca, Morelos \\ 62100, México. \\ veronika.wirtz@insp.mx
}

\begin{abstract}
This study analyzes access to medicines among displaced and non-displaced populations in urban areas in Bucaramanga, Colombia. A household survey was carried out to study access to medicines for self-reported and medically diagnosed health conditions. Multiple Poisson regression with robust variance was used to determine factors associated with access to medicines. Two thousand and sixty individuals from 514 families participated. Only 29.1\% (95\%CI: 22.04-37.08) of the individuals in the sample with prescriptions and 44.3\% (95\%CI: 40.42-48.25) with selfreported needs for pharmacotherapy were taking medicines. Greater access was associated with the perceived severity of the illness, higher income, having a health center nearby and not perceiving barriers in accessing services. Social security affiliation and being displaced were not related. Social security coverage alone does not have an effect on access to medicines because it does not include essential medicines that correspond to the health needs of this population. Resolving administrative and geographical barriers is likely to improve access to medicines.
\end{abstract}

Health Services Accessibility; Vulnerable Populations; Social Security
Myriam Ruiz-Rodríguez ${ }^{1}$

Veronika J. Wirtz 2

Alvaro J. Idrovo 2,3

Mary Lupe Angulo 1

\section{Introduction}

Internal displacement is a demographic process characterized by forced migration without crossing national borders 1 . The United Nations estimated that in 2008 there were 26 million internally displaced people (IDP) worldwide 2 . Colombia, with approximately 3.8 million IDPs, is ranked second on the list of countries with the greatest number of internally displaced people, surpassed only by Sudan, with more than 5 million IDPs. These two countries, along with Angola, have experienced prolonged and aggressive armed conflicts in recent times ${ }^{3}$. According to some reports the increasing number of IDPs has resulted in a continuous rise of poverty in the urban areas ${ }^{4}$. The significant increase of population in these areas has frequently overwhelmed the capacity of local authorities, leading to limited availability, accessibility and coverage of social public services (such as drinking water and sewage) and housing 5 .

In Colombia displacement patterns due to armed conflict are predominantly from rural areas to large cities 6 , particularly to their peripheries, and have resulted in rapid growth with little or no urban development planning 7 . Resettlement zones are characterized by precarious intra-domestic and environmental sanitary conditions and lack of public services ${ }^{8,9}$. Internally displaced people compete for public resources 
with the local population. Having a very low economic status makes these people vulnerable to envy and reinforces their status as unwanted and stigmatized 10 . Internally displaced people have historically lived below the poverty line, have limited opportunities for human development and are subject to psychosocial risks due to the socio-political context of displacement 11,12,13. Various studies have reported poor living and health conditions for IDPs residing in urban reception zones 14,15,16,17,18, as well as a low level of access to curative and preventive medical care 14,19. Research in Colombia has found that around $70 \%$ of IDPs are of ethnic Afro-Colombian and indigenous background and that women, children and black people are most affected by this demographic process 20.

Studies analyzing access to health services in Colombia found that utilization of health services by IDPs with health problems was lower than in the general population, indicating the existence of access barriers 21 which affect access to essential medicines as well as other services 15 . However, there is very little information on the magnitude of the problem of access to medicine among IDPs.

Medicines are the most commonly used therapeutic intervention and, when used appropriately, one of the most cost-effective interventions. Access to essential medicines has been defined as a human right and is one of the targets of the Millennium Development Goals 22. However, according to data from 1999, the World Health Organization estimated that one third of the world's population lacks access to essential medicines 23. Price has been identified as one of the most relevant of the multiple barriers to accessing medicines 24 . In many developing countries out-of-pocket expenditure is the most common form of health care financing and many households spend more than half of their income on medicines and have been found to sell assets in order to obtain medicine 25. Even when they qualify for reimbursement through health insurance medicines may not be available at the point of care or the geographical distance is prohibitive 26,27 . Household surveys can provide relevant data on access to medicines and whether household members were able to obtain the medicines they needed to treat their health problem. Access to medicine is an important indicator for the functioning of the healthcare systems 28 and therefore the evaluation of current strategies in Colombia to improve access to health services and medicine is vital to ensure efficient policy design and implementation. The objective of this study was to evaluate access to medicine among internally displaced people and non-displaced people residing in one of the main urban reception zones in Colombia.

\section{Methods}

\section{Design, population and sample}

The analysis of the data presented is based on the study, Diagnostic Health Survey of Displaced and Non-displaced Populations in Bucaramanga and Surrounding Metropolitan Area, conducted during the second semester of 2003 and approved by the ethics committee at the Industrial University of Santander at Bucaramanga (UIS), Colombia. The study methodology has been described in another publication 21. Briefly, this survey was conducted with displaced and non-displaced families who lived in urban reception zones for persons displaced by armed conflict in the municipalities of Bucaramanga, Piedecuesta, Floridablanca and Giron in the Bucaramanga Metropolitan Area.

Probabilistic sampling was used to select participants and all municipalities were classified in strata. Sample size was calculated based on numbers on the registry of displaced families in each of the four settlements produced by the Social Solidarity Network, a state entity responsible for registering IDPs. According to this source, 5,352 displaced families (approximately 23,549 individuals) were residing in the municipalities studied during the period of study distributed in the following proportions: $57.8 \%$ in Bucaramanga ( $\mathrm{n}=3,093$ families), $19.3 \%$ in Piedecuesta $(\mathrm{n}=$ 1,034 families), $13.7 \%$ in Floridablanca ( $n=734$ families), and $9.2 \%$ in Giron ( $\mathrm{n}=491$ families). The prevalence of illness was considered to be $50 \%$, with a precision of 6 percentage points and a 95\% confidence level. Proportional allocation of the strata was used to determine the sample for each stratum so as to maintain the same relative weighting for the number of families in each stratum, compared to the total of all families in the overall sample. A total of 257 displaced families participated in the study. An equal number of non-displaced families was included in the study (one non-displaced family for each displaced family) thus obtaining the total number of families needed to be sampled in order to capture the existing differences between the two populations. This sampling procedure was considered acceptable for the objectives of the analysis presented in this article.

Individuals were considered internally displaced if they had been forced to migrate within the national territory and abandon their place of residence or usual economic activity, due to 
a direct threat or violation of their life, physical integrity, personal security or liberty or due to the following situations: internal armed conflict, internal disturbances or tensions, generalized violence, massive human rights violations, internal human rights infractions and other circumstances arising from the above situations that could alter or drastically alter the public order 29 .

\section{Data collection}

Data was obtained using structured face-to-face interviews of each of the family members after giving informed consent (for children and older adults with mental disability, their caretakers gave the interview). Less than $5 \%$ of the households refused to take part in the interview. The questionnaire was developed for the present study and a previously piloted study; the data from the pilot study was excluded since modifications were made to the questionnaire. The interview included a section about family structure and housing conditions which was reported by the head of household. A second section asked for information about each family member. All family members were investigated with respect to: (1) socio-demographic data, (2) self-reported health problems present during the previous two weeks, (3) health problems diagnosed by a physician, and (4) whether the household member had used medicines in the last 15 days prior to the survey. Data was collected about the illness for which medicine was being taken, whether it had been prescribed and by whom. Household members who reported to have been taking medicines were asked to show the containers (bottles, boxes, blisters, etc.) in order to record the name of up to a maximum of three products per individual. In addition, for individuals 18 years of age and older, a check list was used to investigate chronic illnesses and other conditions relevant to public health. Those who answered affirmatively to having had one of the chronic illnesses were asked if the illness was being treated by a physician and if its management included the use of medicines. The Zung scale, one of the most commonly used instruments to quantify the depressed status of an individual, was also applied to detect depression, using a version previously validated for the Colombian population ${ }^{30}$. The interview comprised of a total of 20 questions, of which 10 were positively phrased and 10 were negatively phrased, measuring four common characteristics of depression: the pervasive effect, the physiological equivalents, other disturbances and psychomotor activities 30 .

\section{Access to medicines}

Defining the need for and consequently having access to medicines is not straight forward. A need for medicine was defined as having been prescribed a medicine. Lack of access to medicines was classified as an individual being unable to take the prescribed medicines because they were unable to obtain them. The definition of the need of a medicine in the absence of a prescription and based on a self-reported health problem is more complex. In such cases, the need to receive pharmacotherapy was classified as "probable" or "highly probable" based on the likelihood of health problems and subsequent complications resulting from the self-reported illness in the 15 days prior to the survey. We took into consideration the individual and the environmental conditions of internally displaced people without the necessary economic resources to manage health problems, with frequent nutritional deficits and living in inadequate intra-domestic and environmentally unsanitary conditions 31,32 . These conditions increase the burden caused by illness and in such cases the problem should be identified and treated early to avoid complications. The classification "highly probable" need for pharmacotherapy was based upon health problems considered to have a high likelihood of requiring medicines, due to very adverse living conditions (Table 1). Health problems classified as "probable" were symptoms and other problems, where the illness history indicated that a medicine was only required at a certain stage of the illness, which is an aspect that is not possible to ascertain in a self-report.

\section{Statistical methods and analysis}

All categorical variables were described using percentages. Continuous variables were explored with measures of central tendency and dispersion, according to the distribution and then grouped and described using percentages to unify the data presentation. Afterwards, the characteristics of displaced and non-displaced persons were compared using the $\chi^{2}$ test. For each illness, the prevalence of "need of access", and "access" to medicines of those in need was determined using 95\% confidence intervals (95\%CI). Since an individual could present more than one health problem, the sum could surpass $100 \%$.

Finally, using Poisson regression with robust variance, factors associated with access were analyzed. To consider the survey design (municipalities as strata and homes as conglomerates) it was necessary to do the weighting manually. In a previous empirical comparison of alternative 
Table 1

Classification of the need for pharmacotherapy based on health problems.

\begin{tabular}{|c|c|c|c|}
\hline \multirow[t]{2}{*}{ Event } & \multirow[t]{2}{*}{$\begin{array}{l}\text { Medically diagnosed and } \\
\text { prescribed pharmacotherapy }\end{array}$} & \multicolumn{2}{|c|}{$\begin{array}{l}\text { Self-diagnosis with no } \\
\text { medical prescription }\end{array}$} \\
\hline & & Highly probable & Probable \\
\hline Cardiovascular disease, including hypertension & $x$ & & \\
\hline Chronic renal disease & $x$ & & \\
\hline Diabetes mellitus & $x$ & & \\
\hline Epilepsy & $x$ & & \\
\hline Rheumatory arthritis & $x$ & & \\
\hline Cancer & $x$ & & \\
\hline Hyperthyroidism & $x$ & & \\
\hline Leprosy & $x$ & & \\
\hline Chagas disease & $x$ & & \\
\hline Tuberculosis & $x$ & & \\
\hline Asthma & $x$ & $x$ & \\
\hline Acute respiratory infection in children $<3$ years old & $x$ & $x$ & \\
\hline Genitourinary infection & $x$ & $x$ & \\
\hline Skin infection & $x$ & $x$ & \\
\hline Oral cavity infection & $x$ & $x$ & \\
\hline Diarrheal disease in children $<3$ years old & $x$ & $x$ & \\
\hline Intestinal parasite & $x$ & $x$ & \\
\hline Cirrhosis & $x$ & $x$ & \\
\hline Hepatitis & $x$ & $x$ & \\
\hline Lupus erythematosus & $\mathrm{x}$ & $x$ & \\
\hline Transverse myelitis & $x$ & $x$ & \\
\hline Anemia in children $<5$ years old & $x$ & $x$ & \\
\hline Varicose ulcer & $x$ & $x$ & \\
\hline Cephalea migraine & $x$ & & $x$ \\
\hline Non-migraine cephalea & $x$ & & $x$ \\
\hline Body pain other than headache & $x$ & & $x$ \\
\hline Fever & & & $x$ \\
\hline Gastritis & $x$ & & $x$ \\
\hline Allergies & $x$ & & $x$ \\
\hline Acute respiratory infection in children $>3$ years old & $x$ & & $x$ \\
\hline Dengue & $x$ & & $x$ \\
\hline Cystitis & $x$ & & $x$ \\
\hline Erysipelas & $x$ & & $x$ \\
\hline
\end{tabular}

methods to logistic regression, Poisson regression with robust variance was identified as a good option to obtain corrected estimates of prevalence ratios 33 . Thus in this study we interpreted incidence-rate ratios as prevalence ratios (PR). The antiparsimony principle was applied for the purpose of identifying the uncertainty inherent in observational studies that lack randomness 34,35 , where access to medicines was considered to be the dependent variable (yes/no). Independent categorical variables were sex (male/female), being a internally displaced person or not (as defined in the introduction), the municipality of the settlement, affiliation with the health system (affiliated/not affiliated), the type of health problem (acute/chronic), if there was a perceived severity of the illness (yes/no), access barriers (defined as all factors that the household member identi- 
fied as being obstacles to receiving health services and grouped as yes/no), and use of health services during the previous year (yes/no). Independent continuous variables were age, distance to health services $(\mathrm{km})$, and number of family members. The analysis was carried out using the Stata 11 statistical software (Stata Corp., College Station, USA).

\section{Results}

Table 2 presents the characteristics of the study population. A total of 2,060 persons from 514 families participated in the study and $54.6 \%$ of all participants were women. A total of $50.8 \%$ of those interviewed were displaced due to armed conflict. More than half of the population (61\%) was under 20 years of age and the median age was 14 years (minimum: zero in both comparison groups, maximum: 84 and 81 years in non-internally displaced people and internally displaced people, respectively). Level of schooling differed between internally displaced and non-internally displaced people because skewness and kurtosis was higher among non-internally displaced people. The internally displaced people had, on average, been residing in the settlement for less time and had less schooling $(\mathrm{p}<0.05)$. With regard to economic situation and social security, internally displaced people had less income. A total of 511 individuals reported being affiliated with the public health systems (General Social Security Health System - SGSSS, abbreviation in Spanish), of which 180 (35\%) were internally displaced people and 331 (65\%) non-displaced people.

Of the total interviewees, $20.3 \%(n=419)$ reported taking medicines in the 15 days prior to the survey, $14.2 \%(n=293)$ were taking only one medicine, $3.9 \%(\mathrm{n}=81)$ were taking two and $2.2 \%$ $(\mathrm{n}=45)$ were taking three or more medicines. Of the sample, $5.4 \%$ of children under five years of age and $2.1 \%$ adults over the age of 51 took at least one type of medicine (Table 2).

There was no difference between internally displaced people and non-internally displaced people with respect to the probable and highly probable need for pharmacological treatment. With regard to who recommended the medicine, out of a total of 590 medicines, more than half (55.1\%) of medicines were taken due to medical advice, $32.7 \%$ medicines were taken because they were recommended by a family member or friend or self-medication, and $12.1 \%$ were recommended by pharmacy staff. It is interesting to note that internally displaced people reported taking medicines more often based on advice given by a pharmacy $(75.6 \%$ versus $24.4 \%$; $\mathrm{p}=0.001$ ). Since the subsequent analyses used different denominators, a graphical explanation of subsamples is presented in Figure 1. This situation was related to the fact that more than one diagnosis is possible for one individual.

Table 3 shows the principal problems for which the interviewees received a medical prescription which included cardiovascular problems such as arterial hypertension, chronic renal disease, diabetes mellitus and epilepsy. Only 29\% of individuals who received a medical prescription took the medicines prescribed; patients with kidney disease had the lowest level of access. The same table summarizes access to medicines for self-diagnosed health problems or those diagnosed by the Zung scale. In general, $44.3 \%$ of the individuals were able to obtain the medicines needed for the self-diagnosed health problems. It is interesting to note that only four of the 29 individuals interviewed who presented severe depression according to the Zung scale reported receiving treatment. Other health problems in which the majority of individuals did not use medicines included back pain and stomach pain (Table 3).

Table 4 presents the results of the Poisson regression with robust variance used to identify determinants of access to medicines. The perception of severity, use of medical services during the previous year, and higher family income were associated with greater access to medicines. People who had perceived barriers in accessing health services also had less access to medicine. No association was observed between the other variables and access to medicines, including affiliation and being displaced.

\section{Discussion}

Given the lack of quantitative information about access to medicines among internally displaced people, the findings in this study are very relevant to health care policies for this population. Worldwide, forced displacement produces an accumulation of vulnerabilities linked to the loss of political rights and social support networks and family break-up, and poor infrastructure and adverse sanitary and environmental conditions experienced by displaced people in their place of arrival 36,37,38. All of these characteristics increase the risk of death and illness among this population 39,40 . The absence of pharmacological treatment constitutes inequality in access, contributes to deterioration in health status and increases an individual's vulnerability.

Access to medicines was very low among the study population; only $29 \%$ of individuals who 
Table 2

Principal characteristics of study participants.

\begin{tabular}{|c|c|c|c|c|}
\hline & $\begin{array}{l}\text { All participants } \\
\qquad \begin{array}{c}(n=2,060) \\
n(\%)\end{array}\end{array}$ & $\begin{array}{l}\text { Non-displaced people } \\
\qquad(n=1,013) \\
n\end{array}$ & $\begin{array}{c}\text { Internally displaced } \\
\text { people } \\
(n=1,047) \\
n\end{array}$ & p-value * \\
\hline Sex & & & & 0.945 \\
\hline Women & $1,125(54.6)$ & 554 & 571 & \\
\hline Men & 935 (45.4) & 459 & 476 & \\
\hline Age (years) & & & & 0.181 \\
\hline$<5$ & $380(18.4)$ & 194 & 186 & \\
\hline $5-10$ & $444(21.6)$ & 212 & 232 & \\
\hline $11-20$ & $432(21.0)$ & 202 & 230 & \\
\hline $21-30$ & $303(14.7)$ & 146 & 157 & \\
\hline $31-40$ & $262(12.7)$ & 147 & 115 & \\
\hline$>40$ & $239(11.6)$ & 112 & 127 & \\
\hline Time residing in settlement (years) & & & & $<0.001$ \\
\hline$<1$ & $432(21.0)$ & 244 & 188 & \\
\hline 1 to less than 2 & 709 (30.4) & 310 & 399 & \\
\hline 2 to less than 3 & $648(24.9)$ & 282 & 366 & \\
\hline 3 to less than 4 & $271(13.2)$ & 177 & 94 & \\
\hline Schooling (years) & & & & 0.031 \\
\hline None & $171(8.3)$ & 69 & 102 & \\
\hline $1-3$ & $486(23.6)$ & 234 & 252 & \\
\hline $4-6$ & $571(27.7)$ & 289 & 282 & \\
\hline$>6$ & $207(10.0)$ & 114 & 93 & \\
\hline Not applicable because under age & $625(30.3)$ & 307 & 318 & \\
\hline Daily family income (US\$) & & & & 0.001 \\
\hline$\leq 0.35$ & $123(8.6)$ & 70 & 53 & \\
\hline $0.36-1.07$ & $392(19.0)$ & 159 & 233 & \\
\hline $1.08-1.78$ & $572(27.8)$ & 283 & 289 & \\
\hline$\geq 1.79$ & $973(47.2)$ & 501 & 472 & \\
\hline Affiliation status with the SGSSS & & & & $<0.001$ \\
\hline No & $1,549(75.2)$ & 682 & 867 & \\
\hline Yes & $511(24.8)$ & 331 & 180 & \\
\hline Consumption of medicines ** & & & & 0.472 \\
\hline One type of medicine & $293(14.2)$ & 137 & 156 & \\
\hline Two types of medicines & $81(3.9)$ & 44 & 37 & \\
\hline Three types of medicines & $45(2.2)$ & 21 & 24 & \\
\hline None & $1641(79.7)$ & 811 & 830 & \\
\hline Consumption of at least one medicine by age (years) & & & & 0.347 \\
\hline$<5$ & $112(5.4)$ & 55 & 57 & \\
\hline $5-15$ & $100(4.9)$ & 46 & 54 & \\
\hline $16-30$ & $82(4.0)$ & 40 & 42 & \\
\hline $31-50$ & $81(3.9)$ & 45 & 36 & \\
\hline$>51$ & $44(2.1)$ & 16 & 28 & \\
\hline $\begin{array}{l}\text { Not taking medicines within } 15 \text { days prior to the } \\
\text { survey }\end{array}$ & $1,641(79.7)$ & 811 & 830 & \\
\hline
\end{tabular}

SGSSS: General Social Security Health System.

Note: 2,060 was the total number of study participants.

* $\chi^{2}$ test to probe for statistically significant differences between non-displaced and displaced group;

** A total of 590 medicines were reported. 


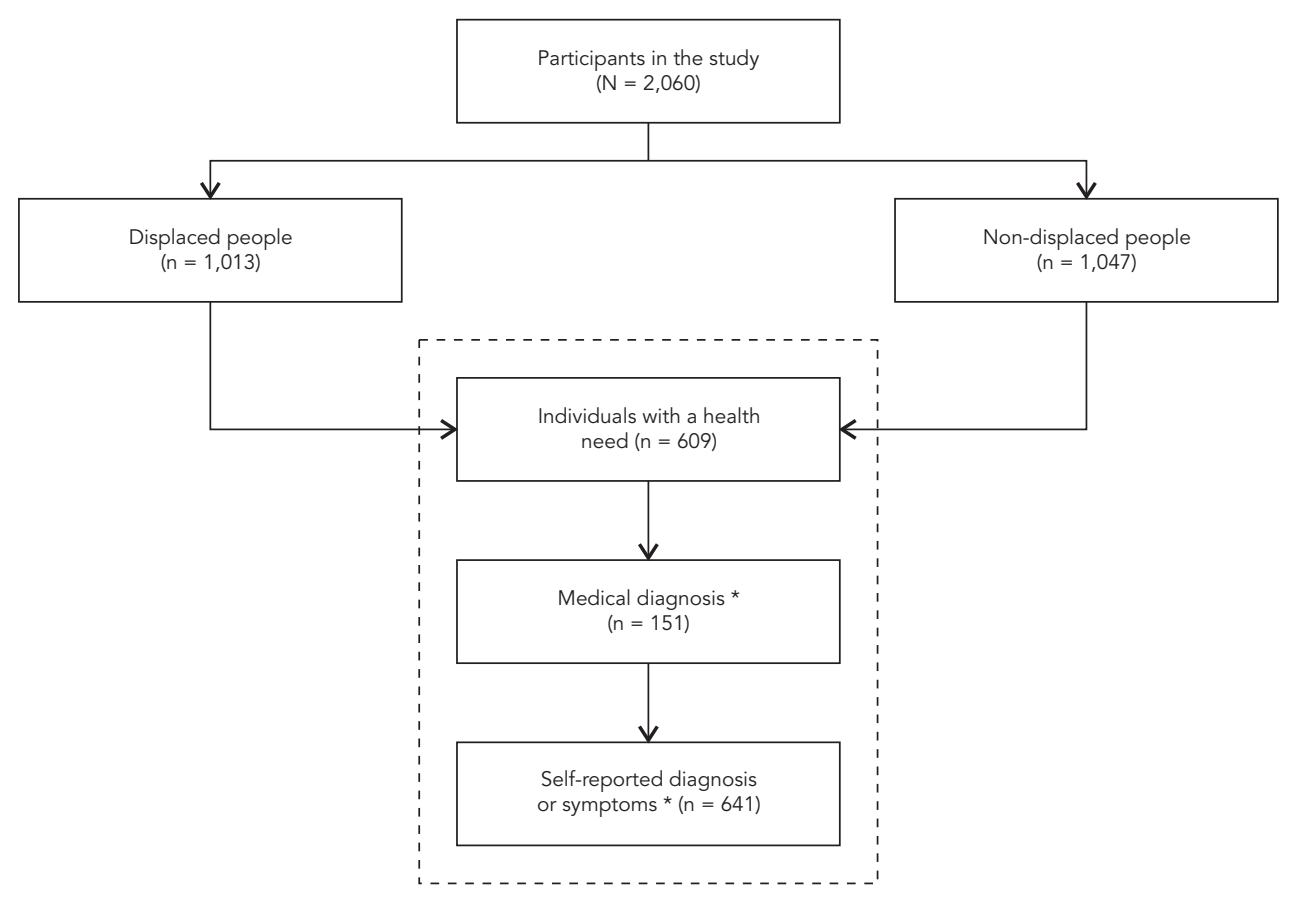

* One individual may have one or more medical condition, self-reported diagnosis, or symptoms.

received prescriptions for medicines were able to obtain them, and of those who reported symptoms that were classified as indicators of illnesses where the need for pharmacological treatment was probable or highly probable, less than half (44.3\%) were taking medicines.

Of particular concern is the lack of use of medicines for treating mental illnesses. Different studies have shown that mental health problems among displaced and refugee populations are prevalent 41,42 and in some cases can persist for long periods of time after the displacement event occurs 41 . In other populations, it has been found that psychiatric morbidity and an unfavorable health prognosis are associated with unfavorable socioeconomic conditions 42 and, therefore, pharmacological treatment could be an alternative to improving an individual's health status. Puertas et al. 18 reported that prevalence of common mental disorders is greater in areas with both internally displaced people and noninternally displaced people as opposed to only non-displaced people.

One of the most important findings in this study, which was unexpected in light of the au- thors' hypothesis before conducting the study, is that access to medicines is not associated with the condition of being displaced due to armed conflict or with having medical insurance; thus other barriers in accessing medicines exist that prevent their use. There are multiple reasons why medical insurance may be failing to provide access to medicines, including the fact that some medicines are not included in the health plan 16,39, and bureaucratic problems such as long distances in travelling to the pharmacies, very limited time, and excessive paperwork for releasing medicines supplied by the insurer 16 . Other authors have discussed the lack of impact of health insurance on access to medicines for other low and middle income countries 43 .

Another important result of our study is that access was associated with the perceived severity of the illness, indicating that families give priority to children and perceived serious illnesses. Other studies of vulnerable populations have reported that perceived severity of illness in children is a factor that influences health seeking behavior 44 . There is also a direct association with income which suggests that economic variables have a 
Table 3

Frequency of diagnosis reported and medicines available for treatment.

\begin{tabular}{|c|c|c|c|c|}
\hline \multirow[t]{2}{*}{ Events } & \multirow{2}{*}{$\begin{array}{c}\text { Number of times the diagnosis } \\
\text { was mentioned } \\
n\end{array}$} & \multicolumn{3}{|c|}{$\begin{array}{l}\text { Number of times a medicines was available } \\
\text { for treatment }\end{array}$} \\
\hline & & $\mathrm{n}$ & $\%$ & $95 \% \mathrm{Cl}$ \\
\hline \multicolumn{5}{|l|}{ Disease diagnosed by a physician $(n=151)$} \\
\hline Cardiovascular disease, including hypertension & 80 & 28 & 35.00 & $24.67-46.48$ \\
\hline Chronic renal disease & 29 & 4 & 13.80 & $3.89-31.66$ \\
\hline Diabetes mellitus & 18 & 5 & 27.78 & $9.69-53.48$ \\
\hline Epilepsy & 9 & 4 & 44.44 & $13.7-78.8$ \\
\hline Rheumatoid arthritis & 6 & 0 & 0.00 & ND \\
\hline Cancer & 3 & 0 & 0.00 & ND \\
\hline Hyperthyroidism & 2 & 1 & 50.00 & $1.26-98.74$ \\
\hline Leprosy & 2 & 0 & 0.00 & ND \\
\hline Chagas disease & 1 & 1 & 100.00 & \\
\hline Tuberculosis & 1 & 1 & 100.00 & \\
\hline \multicolumn{5}{|l|}{ Self-report of diagnosis or symptoms $(n=641)$} \\
\hline Respiratory & 230 & 108 & 47.00 & $40.4-53.6$ \\
\hline Flu & 181 & 75 & 41.40 & $34.2-49.0$ \\
\hline Cough & 21 & 11 & 52.40 & $29.8-74.3$ \\
\hline Asthma & 16 & 12 & 75.00 & $47.6-92.7$ \\
\hline Others & 12 & 10 & 83.30 & $51.6-97.9$ \\
\hline Digestive & 104 & 39 & 37.50 & $28.2-47.5$ \\
\hline Diarrhea & 48 & 22 & 45.80 & $31.4-60.8$ \\
\hline Stomach pain & 28 & 9 & 32.10 & $15.9-52.4$ \\
\hline Others & 28 & 8 & 28.60 & $13.2-48.7$ \\
\hline Osteomuscular and connective tissue & 50 & 17 & 34.00 & $21.2-48.8$ \\
\hline Back pain & 29 & 6 & 20.70 & $8.0-39.7$ \\
\hline Joint pain & 11 & 6 & 54.60 & $23.4-83.3$ \\
\hline Others & 10 & 5 & 50.00 & $18.7-81.3$ \\
\hline Other events & 257 & 120 & 46.70 & $40.5-53.0$ \\
\hline Headache & 89 & 43 & 48.30 & $37.6-59.2$ \\
\hline Severe depression * & 29 & 4 & 13.70 & $3.9-31.7$ \\
\hline Fever & 18 & 12 & 66.70 & $41.0-86.7$ \\
\hline Dengue & 17 & 9 & 52.90 & $27.8-77.0$ \\
\hline Skin infections & 17 & 11 & 64.70 & $38.3-85.8$ \\
\hline Others & 87 & 41 & 47.10 & $36.3-58.1$ \\
\hline
\end{tabular}

ND: not defined; 95Cl\%: 95\% confidence interval.

* According to Zung test.

strong influence on access even though the study population has precarious economic resources, demonstrating that there is unequal access due to a family's economic position. Socioeconomic factors have been shown to influence the ability to obtain medicines in other settings 45 . The fact that no association was found between insurance coverage and access to medicines and that there was an association between income and access suggest that the performance of the health system in Colombia in terms of providing access for people living in poverty or displaced by armed conflict needs to improved; this is in line with other studies that have shown how the structure of the Colombian health system might affect access to health services 16 .

The population studied was very young, with half being less than 20 years old. Therefore, acute problems such as diarrhea were very frequent in this population. Given that the inappropriate use of medicines for gastro-intestinal illnesses in children in low-income countries is well document- 
Crude prevalence ratio (PR) and adjusted prevalence ratio (aPR) between access to medicines and potential determinants.

\begin{tabular}{|c|c|c|c|c|}
\hline Variable & PR & $95 \% \mathrm{Cl}$ & $\mathrm{aPR}$ * & $95 \% \mathrm{Cl}$ \\
\hline \multicolumn{5}{|l|}{ Sex } \\
\hline Female & 1.00 & & 1.00 & \\
\hline Male & 1.00 & $0.98-1.02$ & 0.99 & $0.97-1.02$ \\
\hline Age (years completed) & 0.99 & $0.99-1.00$ & 0.99 & $0.98-1.00$ \\
\hline \multicolumn{5}{|c|}{ Family displaced due to armed conflict } \\
\hline No & 1.00 & & 1.00 & \\
\hline $\mathrm{Si}$ & 0.99 & $0.97-1.02$ & 1.01 & $0.98-1.03$ \\
\hline \multicolumn{5}{|l|}{ Affiliation status with the SGSSS } \\
\hline Not affiliated & 1.00 & & 1.00 & \\
\hline Affiliated & 1.02 & $0.99-1.04$ & 1.01 & $0.98-1.03$ \\
\hline \multicolumn{5}{|l|}{ Type of health problem } \\
\hline Acute & 1.00 & & 1.00 & \\
\hline Chronic & 1.02 & $0.99-1.06$ & 1.03 & $0.99-1.07$ \\
\hline \multicolumn{5}{|c|}{ Perceived seriousness of health problem } \\
\hline No & 1.00 & & 1.00 & \\
\hline Yes & 1.06 & $1.03-1.09$ & 1.07 & $1.04-1.10$ \\
\hline \multicolumn{5}{|l|}{ Perceived barriers to access } \\
\hline No & 1.00 & & 1.00 & \\
\hline Yes & 0.95 & $0.93-0.97$ & 0.94 & $0.91-0.96$ \\
\hline \multicolumn{5}{|c|}{ Use of medical services during the previous year } \\
\hline No & 1.00 & & 1.00 & \\
\hline Yes & 1.05 & $1.03-1.08$ & 1.68 & $1.12-2.52$ \\
\hline Distance to health center $(\mathrm{km})$ & 1.00 & $0.99-1.01$ & 1.01 & $0.99-1.02$ \\
\hline Daily family income (US\$) & 1.01 & $1.00-1.02$ & 1.02 & $1.00-1.03$ \\
\hline Number of family members & 1.00 & $0.99-1.01$ & 1.01 & 0.99-1.01 \\
\hline
\end{tabular}

SGSSS: General Social Security Health System; $95 \% \mathrm{Cl}$ : 95\% confidence interval.

Note: $\mathrm{n}=609$ individuals in total.

* Approximation obtained using incidence-rate ratios of multiple Poisson regression with robust variance.

ed 46 , it would be important to include strategies to encourage the appropriate use of medicines in programs for improving access to them. Patterns for seeking advice about medicines were distinct: more internally displaced people used pharmacies as a source of obtaining advice about which medicine they should take. Since only one-third of internally displaced people have health insurance, it is possible that the pharmacy was an alternative for seeking care since the consultation for the health problem is free.

Although the study was conducted in a large metropolitan area in Colombia, the characteristics of the population studied are similar to those of other populations that live in other reception zones for displaced people 9 . Hence, the findings of the investigation can serve as a guide for improving access to medicines in other displacement situations. Given the general paucity of lit- erature about access to and the use of medicines, the findings are also relevant for other countries. This study is based on participant self-reports of health problems where highly probable access and probable access were defined based on the information given by the interviewees. This information could be biased due to memory and other factors. Nevertheless, our results are consistent with other studies conducted with displaced and non-displaced poor populations 9,12,14,19, which indicate low rates of access to preventive and curative health services. This suggests that barriers for accessing health services are systematic for this type of population living in urban areas in situations of poverty and displacement. Only up to three types of medicines were recorded since previous studies had shown that most members of internally displaced people households were not taking more than three types of medicines 47 . 
As far as we know, this is the first study to quantify access to and the use of medicines by internally displaced people in Colombia. The findings of this study inform the following recommendations for the design and/or adjustment of pharmaceutical policies and for health programs and policies geared towards internally displaced people in general: (i) policies for access to pharmacological treatment should be focused not only on displaced people but also on individuals who live in similar poverty conditions. In Colombia in recent years there has been a large emphasis on programs focused on displaced people, discriminating against non-displaced populations that live in similar conditions 14 . As the results show that both groups have a low level of access to medicines, policies should be similar for the two groups; (ii) coverage of social security alone does not have an effect on access to medicines if it does not include essential medi- cines that respond to the real health problems of this population (for example, mental health problems) and if it does not decrease administrative and geographical barriers that prevent such access; (iii) access particularly to mental health care and care for chronic illnesses is crucial in responding to the specific needs of the population. We found that the need of pharmacological treatment was highly probable in $23 \%$ of the individuals that responded to the Zung test, while the large majority of individuals (86\%) were not receiving treatment. Internationally, the need to offer mental health care in emergency situations such as displacement has been recognized 48 , and (iv) the pharmacy has a relevant role in providing access to medicines and giving advice about their use; therefore, health promotion and prevention programs should use the pharmacy as part of the health system and offer training to personnel to promote the appropriate use of medicines.

\section{Resumen}

Este estudio analiza el acceso a medicamentos de desplazados y no desplazados en Bucaramanga, Colombia. A través de una encuesta de hogares se estudió acceso a medicamentos para condiciones de salud auto-reportadas y diagnosticadas. Un modelo de regresión Poisson con varianza robusta fue usado para determinar los factores asociados con el acceso a medicamentos. De los 2.060 individuos de 514 familias participantes solo 29,1\% (IC95\%: 22,04-37,08) y 44,3\% (IC95\%: 40,42-48,25) de los participantes con prescripción y necesidad auto-reportada de farmacoterapia estaban tomando medicamentos. El mayor acceso estuvo asociado con severidad percibida de la enfermedad, mayor ingreso, cercanía de un centro de salud y no percepción de barreras para acceder a servicios. La afiliación a la seguridad social y ser desplazado no estuvieron relacionadas. La cobertura de la seguridad social no tiene efecto sobre el acceso a medicamentos si no incluye medicamentos que respondan a las necesidades de salud de la población. Disminuir las barreras administrativas podría promover el acceso a medicamentos.

Accesibilidad a los Servicios de Salud; Poblaciones Vulnerables; Seguridad Social

\section{Contributors}

M. Ruiz-Rodríguez contributed to the conception and design of his study, data analysis and interpretation writing the manuscript and approved the final version of this manuscript. V. J. Wirtz and A. J. Idrovo wrote the manuscript and contributed to data analysis and interpretation and approved the final version of this manuscript. M. L. Angulo contributed to the conception and design of his study, and approved the final version of this manuscript.

\section{Acknowledgments}

We are grateful to the Industrial University of Santander at Bucaramanga (UIS), Colombia and the Pan American Health Organization for their support in carrying out this study. 


\section{References}

1. Brookings Institution. Handbook for applying the guiding principles on internal displacement. Washington DC: Brookings Institute; 1999.

2. Internal Displacement Monitoring Centre. Internal displacement: global overview of trends and developments in 2008. Geneva: Internal Displacement Monitoring Centre; 2009.

3. Cohen R. The guiding principles on internal displacement: an innovation in international standard setting. Global Governance 2004; 10:459-80.

4. Comité Internacional de la Cruz Roja; Programa Mundial de Alimentos. Identificación de las necesidades alimentarias y no alimentarias de los desplazados internos en Colombia. Bogotá: Comité Internacional de la Cruz Roja/Programa Mundial de Alimentos; 2005.

5. World Bank. Colombia. Poverty report. Volume I: main report. Washington DC: World Bank; 2002.

6. Consultoría para el Desplazamiento Forzado y los Derechos Humanos; Únete por la Niñez. Un país que huye: desplazamiento y violencia en una nación fragmentada. Bogotá: Únete por la Niñez; 1999.

7. Zafra-Roldán G. Los desplazados internos por la violencia: un problema fundamental en Colombia. http://www.oas.org/juridico/Spanish/zafra.html (accessed on 04/Mar/2011).

8. Consultoría para los Derechos Humanos y el Desplazamiento. Más o menos desplazados. Bogotá: Consultoría para los Derechos Humanos y el Desplazamiento; 2006. (Codhes Informa: Boletín, 69).

9. Angulo ML, López-Barbosa N, Vera-Cala L, RuizRodríguez M, Peña-Villamizar ML, Ríos-Marín LS. Salud y desplazamiento en Colombia: comparación de la situación en salud, entre población en situación de desplazamiento y receptora en seis ciudades colombianas 2002-2003. Módulo 3 Bucaramanga. Bogotá: Organización Panamericana de la Salud/Universidad de Antioquia; 2005.

10. Castillejo A. Poética de lo otro, para una antropología de la guerra, la sociedad y el exilio interno en Colombia. Bogotá: Universidad Nacional de Colombia; 2000.

11. Porter M, Haslam N. Predisplacement and postdisplacement factors associated with mental health of refugees and internally displaced personas: a meta-analysis. JAMA 2005; 294:602-12.

12. Cáceres D, Izquierdo V, Mantilla L, Jara J, Velandia M. Perfil epidemiológico de la población desplazada por el conflicto armado interno del país en un barrio de Cartagena, Colombia, 2000. Biomédica (Bogotá) 2002; 22:425-44.

13. Leus $X$, Wallace $M$, Loretti A. Internally displaced persons. Prehosp Disaster Med 2001; 16:116-23.

14. Arias S. Análisis de género de la situación de salud de la población desplazada y no desplazada en cuatro asentamientos marginales de Medellín [Disertación de Maestría]. Medellín: Facultad Nacional de Salud Pública, Universidad de Antioquia; 2002.
15. Mogollón A, Vázquez-Navarrete ML, García M. Necesidades en salud percibidas por la población desplazada por conflicto armado en Bogotá, Colombia. Rev Esp Salud Pública 2003; 77:257-66.

16. Mogollón-Pérez AS, Vázquez ML Factores que inciden en el acceso de la población desplazada a las instituciones prestadoras de servicios de salud en Colombia. Cad Saúde Pública 2008; 24:745-54.

17. Mogollón-Pérez AS, Vázquez-Navarrete ML. Opinión de las mujeres desplazadas sobre la repercusión en su salud del desplazamiento forzado. Gac Sanit 2006; 20:260-5.

18. Puertas G, Ríos C, Valle HD. Prevalencia de trastornos mentales comunes en barrios marginales urbanos con población desplazada en Colombia. Rev Panam Salud Pública 2006; 20:324-30.

19. Ruiz-Rodríguez RM, Vera CL, López BN. Seguro de salud y cobertura de vacunación en población infantil con y sin experiencia de desplazamiento forzado en Colombia. Rev Salud Pública (Bogotá) 2008; 10:49-61.

20. Gómez-Builes GM, Astaiza-Arias GM, Minayo MCS. Las migraciones forzadas por la violencia: el caso de Colombia. Ciênc Saúde Coletiva 2008; 13:1649-60.

21. Ruiz-Rodríguez M, López-Moreno S, Avila-Burgos L, Acosta-Ramírez N. Utilización de servicios médicos por una población desplazada en Bucaramanga, Colombia. Rev Salud Pública (Bogotá) 2006; 8:197-206.

22. United Nations. Millennium Development Goal 8. The global partnership for develop at a critical juncture. New York: United Nations; 2010. (MDG Gap Task Force Report 2010).

23. World Health Organization. World medicines situation. Geneva: World Health Organization; 2004.

24. World Health Organization; World Trade Organization. Report of the workshop on differential pricing and financing of essential drugs. Oslo: Norwegian Foreign Affairs Ministry, Global Health Council; 2001.

25. Kruk ME, Goldmann E, Galea S. Borrowing and selling to pay for health care in low- and middleincome countries. Health Aff (Millwood) 2009; 28:1056-66.

26. Alliance for Health Policy and Systems Research; World Health Organization. Access to medicines research. Geneva: World Health Organization; 2010.

27. van Doorslaer E, O'Donnell O, Rannan-Elyia R, Somanathan A, Adhikari SR, Garg CC, et al. Catastrophic payments for health care in Asia. Health Econ 2007; 16:1159-84.

28. Wiedenmayer K. Access to medicines. Medicine supply: lessons learnt in Tanzania and Mozambique. Basel: Swiss Agency for Development and Coorperation; 2004. 
29. República de Colombia. Ley 387 de 1997. Por la cual se adoptan medidas para la prevención del desplazamiento forzado; la atención, protección, consolidación y estabilización socioeconómica de los desplazados internos por la violencia en la República de Colombia. Diario Oficial 1997; 24 jul.

30. Campo A, Díaz LA, Rueda GE. Validez de la escala breve de Zung para tamizaje del episodio depresivo mayor en la población general de Bucaramanga, Colombia. Biomédica (Bogotá) 2006; 26:415-23.

31. Macinko JA, Shi L, Starfield B, Wulu JT. Income inequality and health: a critical review of the literature. Med Care Res Rev 2003; 60:407-52.

32. Cheung AM, Hwang SW. Risk of death among homeless women: a cohort study and review of the literature. Can Med Assoc J 2004; 170:1243-7.

33. Barros AJD, Hirakata VN. Alternatives for logistic regression in cross-sectional studies: an empirical comparison of models that directly estimate the prevalence ratio. BMC Med Res Methodol 2003; 3:21.

34. Draper D. Assessment and propagation of uncertainty. J R Stat Soc Series B Stat Methodol 1995; 57:45-97.

35. Brenner H, Blettner M. Controlling for continuous confounders in epidemiologic research. Epidemiology 1997; 8:429-34.

36. Cookson ST, Carballo M, Nolan CM, Keystone JS, Jong EC. Migrating populations: a closer view of who, why, and so what. Emerg Infect Dis 2001; 7(3 Suppl):551.

37. Bello M. Desplazamiento forzado en Colombia: acumulación de capital y exclusión social. Bogotá: Universidad Nacional de Colombia; 2003.

38. Waldman R, Martone G. Public health and complex emergencies: new issues, new conditions. Am J Public Health 1999; 89:1483-5.

39. Murray C, King J, Lopez A, Tomijima N, Krug E. Armed conflict as a public health problem. BMJ 2002; 324:346-9.

40. Mollica RF, Sarajlic N, Chernoff M, Lavelle J, Vukovic IS, Massagli MP. Longitudinal study of psychiatric symptoms, disability, mortality, and emigration among Bosnian refugees. JAMA 2001; 286 : 546-54.
41. Alejo Castillo EG, Rueda Jaimes GE, Ortega M, Orozco LC. Estudio epidemiológico del trastorno por estrés postraumático en población desplazada por la violencia política en Colombia. Univ Psychol 2007; 6:623-35.

42. Lorant V, Deliège D, Eaton W, Robert A, Philippot $\mathrm{P}$, Ansseau M. Socioeconomic inequalities in depression: a meta-analysis. Am J Epidemiol 2003; 157:98-112.

43. Wagner AK, Graves AJ, Reiss SK, LeCates R, Shang F, Ross-Degnan R. Access to care and medicines, burden of health care expenditures and risk protection: results from the World Health Survey. Health Policy 2011; 100:151-8.

44. Sreeramareddy CT, Shankar RP, Sreekumaran BV, Subba SH, Joshi HS, Ramachandran U. Care seeking behaviour for childhood illness: a questionnaire survey in western Nepal. BMC Int Health Hum Rights 2006; 6:7.

45. Tediosi F, Aye R, Ibodova S, Thompson R, Wyss K. Access to medicines and out of pocket payments for primary care: evidence from family medicine users in rural Tajikistan. BMC Health Serv Res 2008, 8:109.

46. Weisstaub G, Araya M. Acute malnutrition in Latin America: the challenge of ending avoidable deaths. J Pediatr Gastroenterol Nutr 2008; 47 Suppl 1:S10-4.

47. Albarracín G, Ruiz M, Gómez G, Gamboa M, Garrido J. Uso de medicamentos en poblaciones en desventaja social. Condiciones de manejo y almacenamiento. Bucaramanga: Universidad Industrial de Santander; 2000 .

48. Mollica RF, Cardozo BL, Osofsky HJ, Raphael B, Ager A, Salama P. Mental health in complex emergencies. Lancet 2004; 364:2058-67.

Submitted on 07/Mar/2011

Final version resubmitted on 02/Apr/2012

Approved on 29/Aug/2012 